\title{
PEREMPUAN DAN HAK ȦSASI MANUSIA DALAM PERSPEKTIF HUKUM ISLAM
}

\author{
Uswatun Hasanah ${ }^{1}$
}

Abstrak

In Islamic law, there are principles of equality among all human beings, including equality between men and women. To manifest the principles of equality, proper understanding of Islamic law and human rights is needed. Human rights, including women's rights are often mentioned in al-Qur'an and al-Hadits. Islam comes to bring fresh air for women because God's revelation descended to Prophet Muhammad talks much about women, both about their rights and obligations. Although Islam has been present for more than fourteen centuries ago, but the provisions contained in al-Qur'an and the al-Hadith, as sources of Islamic law have not been realized properly in Islamic society, even until today there are still practices in Islamic communities that put Muslims women not as they should. Although there were not many, but the condition can lead to incorrect understanding of Islam in society that Islam less aware of women's rights. In fact, Islam gives great attention and gives a respectable position for women. In order that the women's rights can be implemented appropriately, every Muslim should understand Islamic law well and correctly, so they can realize their rights and obligations as servants of God, as members of society and citizens. Human rights and women issues should be perceived as a problem faced not by women only, but also by all people in society. Awareness about women's rights in Islam cannot establish by itself but must be cultivated through a correct dissemination of correct understanding to the community, particularly Muslims, both men and women.

Kata kunci: perempuan, hak asasi manusia, hukum Islam

\section{Pendahuluan}

Dalam al-Qur'an disebutkan bahwa Allah SWT. menciptakan segala sesuatu berpasang-pasangan, dan dalam berpasang-pasangan tersebut selalu ada persamaan dan perbedaan. Agar manusia dapat bekerjasama untuk

${ }^{1}$ Guru Besar Hukum Islam Fakultas Hukum Universitas Indonesia. Alamat kontak: uswahhdm@yahoo.co.id 
mencapai cita-cita kemanusiaan, maka persamaan dan perbedaan itu perlu diketahui. Harus diakui bahwa dalam masyarakat Islam masih sering terjadi kepincangan antara hak perempuan dan hak laki-laki. Laki-laki sering mendapatkan kesempatan yang lebih luas dibandingkan dengan perempuan. Sebagai khalifah Allah di bumi, tugas perempuan bukanlah hanya sekedar mendampingi laki-laki, tetapi seharusnya mempunyai tugas yang sama yakni membangun masyarakat. Laki-laki dan perempuan sudah seharusnya menciptakan kondisi harmonis dalam masyarakat sesuai dengan kodrat dan kemampuan masing-masing. Oleh karena itu semua pihak harus mengetahui dan memahami kelebihan dan kekurangan masing-masing. Akibat adanya persamaan dan perbedaan dalam hal-hal tertentu, tidak menjadikan keduanya sepenuhnya sama. Meskipun demikian, ketidaksamaan itu tidak mengurangi kedudukan di satu pihak dan melebihkan di pihak yang lain. Persamaan dalam hal ini harus diartikan kesetaraan, dan bila kesetaraan dalam hal itu terpenuhi, maka keadilanpun akan terwujud karena keadilan tidak selalu berarti persamaan. ${ }^{2}$ Permasalahannya, sampai saat ini kesetaraan dan keadilan tersebut belum sepenuhnya dirasakan oleh kaum perempuan, termasuk perempuan muslimah. Peran serta perempuan dalam kehidupan bermasyarakat, berbangsa dan bernegara tetap terbatas, dan selalu didominasi oleh kaum laki-laki. Nuansa demikian tercermin dalam berbagai bidang, seperti bidang sosial, hukum, ekonomi, politik, dan lain-lain. Walaupun sudah cukup banyak perempuan yang menduduki berbagai jabatan, namun jika dibandingkan dengan laki-laki, kesempatan yang diberikan kepada perempuan masih jauh dari yang diharapkan. Di samping itu, kekerasan terhadap perempuan, termasuk kekerasan dalam rumah tangga masih menjadi bahasan yang belum terselesaikan. Laporan terjadinya kekerasan terhadap perempuan yang masuk ke sejumlah lembaga perlindungan perempuan tidak henti-hentinya dari waktu ke waktu. Hal ini merupakan masalah serius yang harus segera ditangani.

Berbagai upaya untuk melindungi hak-hak perempuan dan membebaskan merka dari pelanggaran hak asasi manusia (HAM) telah lama diperjuangkan melalui berbagai instrumen hukum internasional, bahkan dalam hukum Islam hak-hak perempuan dengan tegas disebutkan dalam alQur;an dan al-Hadits, namun dalam kehidupan sehari-hari hak-hak merka masih tetap terabaikan. Perempuan termasuk perempuan muslimah, sebagaimana dengan laki-laki juga mendambakan perlakuan yang adil dan terbebaskan dari perlakuan diskriminatif dan kekerasan oleh siapapun, di manapun dan dalam kondisi apapun. Untuk mewujudkan kesetaraan dan

hal. 2-6.

${ }^{2}$ M. Quraish Shihab, "Perempuan", Cetakan ke V, (Tangerang: Lentera Hati, 2009), 
keadilan antara perempuan dengan laki-laki dalam Islam bukanlah perkara yang mudah, karena harus mengubah paradigma yang selama ini tertanam dalam segala aspek dan sendi-sendi kehidupan. Bagaimana sebenarnya hakhak perempuan dalam hukum Islam, dan bagaimana pula hukum Islam melindungi hak-hak perempuan? Untuk mengetahui masalah ini, maka kajian tentang perempuan, hak asasi manusia dan hukum Islam perlu dilakukan.

\section{Kedudukan Perempuan dalam Hukum Islam}

Kedudukan seseorang baik perempuan maupun laki-laki tidak mungkin dapat dilaksanakan dengan baik kalau tidak jelas kedudukan orang yang bersangkutan dalam suatu pola kehidupan tertentu, sebab kedudukan adalah tempat yang diduduki oleh seseorang dalam pola tertentu itu. Seseorang mungkin saja mempunyai berbagai kedudukan, karena ia ikut serta dalam berbagai pola kehidupan masyarakat. Hal ini berarti bahwa kedudukan menunjuk pada tempat seseorang dalam kerangka masyarakat secara keseluruhan. Setiap manusia yang menjadi anggota masyarakat, senantiasa mempunyai kedudukan tertentu dan berperan sesuai dengan kedudukannya. Kedudukan dan peranan tidak mungkin dipisahkan, karena peranan adalah aspek dinamis dari kedudukan. Tidak ada peranan tanpa kedudukan dan tidak ada kedudukan tanpa peranan yang memberikan hak dan kewajiban kepada orang yang bersangkutan. Untuk menentukan hak dan kewajiban seorang perempuan, terlebih dahulu harus dikaji kedudukannya. ${ }^{3}$

Kedudukan wanita di masyarakat bukanlah hal yang baru, tetapi juga bukan masalah yang sudah terselesaikan dengan baik. Posisi Islam dalam masalah ini sering dikaburkan oleh sebagian penulis yang hanya menekankan pada praktik yang dilakukan oleh sebagian masyarakat tanpa melihat secara obyektif pada prinsip-prinsip yang terdapat dalam al-Qur'an dan al-Hadits, pada hal sumber utama dan pertama dalam mempelajari Islam dan hukum Islam adalah al-Qur'an, yang kemudian disusul dengan sumber kedua, yakni al-Hadits. Seseorang yang mengkaji Islam bukan dari sumbernya akan menyebabkan orang tersebut salah paham terhadap Islam, apalagi jika kajian tersebut hanya didasarkan pada praktik yang dilakukan oleh sekelompok masyarakat, karena tidak jarang praktik yang dilakukan umat Islam tidak sesuai dengan ketentuan yang ditetapkan Allah dalam al-Qur'an. Hal ini pernah diingatkan oleh Mohammad Qutb, Guru Besar Universitas King Abdul Aziz, bahwa orang yang ingin memahami Islam dengan baik dan

${ }^{3}$ Mohammad Daud Ali dan Habibah Daud, "Lembaga-lembaga Islam di Indonesia", (Jakarta: PT. RajaGrafindo Persada, 1995), hal. 195-196. 
benar, ada beberapa hal yang harus diperhatikan. Beberapa di antaranya adalah sebagai berikut: (a) Islam harus dipelajari dari sumbernya yang asli yakni al-Qur'an yang memuat wahyu-wahyu Allah dan al-Hadits yang memuat Sunnah Nabi Muhammad saw; (b) Islam tidak dipelajari secara parsial, tetapi secara integral. Artinya Islam tidak dipelajari secara sepotongsepotong, tetapi keseluruhan dan dipadukan dalam satu kesatuan yang bulat; (c) Islam dipelajari dari karya atau kepustakaan yang ditulis oleh merka yang telah mengkaji dan memahami Islam secara baik dan benar. Analisis dan kesimpulan para orientalis, kecuali karya yang sudah diakui atau diberi catatan pembenaran oleh sarjana muslim, sebaiknya dihindari oleh orang yang baru belajar tentang Islam, terutama tulisan para orientalis sebelum perang dunia kedua; (d) dalam mempelajari Islam harus dihubungkan dengan berbagai persoalan asasi yang dihadapi manusia dalam masyarakat dan dilihat relasi dan relevansinya dengan persoalan politik, ekonomi, sosial, budaya sepanjang sejarah terutama sejarah umat Islam; (e) dalam memahami Islam hendaknya dengan bantuan ilmu pengetahuan yang berkembang sampai sekarang, seperti ilmu-ilmu alamiah, ilmu-ilmu sosial dan budaya serta ilmu-ilmu kemanusiaan (humaniora). Ketiga bidang ilmu ini beserta cabang dan rantingnya merupakan ilmu-ilmu bantu dalam mengkaji dan memahami Islam; (f) mempelajari Islam dengan metode yang selaras dengan agama dan ajaran Islam. Menurut Ali Syariati, orang yang akan mempelajari agama dan ajaran Islam tidak dapat hanya memilih satu metode tunggal dari sekian banyak metode yang dapat digunakan, karena Islam bukanlah agama yang unidimensional. Untuk mempelajari Islam yang banyak dimensinya, selain dari metode filosofis orang harus mempergunakan juga metodemetode lain yang berkembang sekarang ini seperti metode sejarah dan sosiologi; (g) dalam mempelajari Islam tidak boleh menyamakan Islam dengan umat Islam, terutama dengan keadaan umat Islam pada suatu masa di suatu tempat. Penjajahan Barat yang melanda umat Islam selama berabadabad telah menyebabkan umat Islam berada dalam keadaan lemah, miskin, terbelakang, terpecah-pecah dalam berbagai firkah atau kelompok-kelompok. Keadaan yang seperti ini sering menyebabkan para ahli ilmu-ilmu sosial menarik kesimpulan yang tidak sebagaimana mestinya. ${ }^{4}$ Dalam mempelajari kedudukan perempuan dalam Islam, hal-hal yang harus diperhatikan dalam mempelajari agama dan ajaran Islam juga harus dipertimbangkan.

Fakta sejarah menunjukkan bahwa secara umum kondisi perempuan pada pra-Islam adalah suram. Pada masa itu perempuan yang mempunyai jasa melahirkan manusia di dunia ini dihina, diperlakukan kasar dan

${ }^{4}$ Mohammad Daud Ali, "Pendidikan Agama Islam", (Jakarta: PT. RajaGrafindo Persada, 1998), hal. 83. 
direndahkan martabatnya. Kadangkala merka dipaksa untuk mengabdi kepada suaminya dan diperlakukan seenaknya, bahkan seringkali keberadaan merka tidak diakui sebagai mana mestinya, sehingga merka tidak mempunyai hak dan kedudukan apapun dalam masyarakat. Perempuan pada masa itu tidak diberi kesempatan untuk mengembangkan kepribadian dan menggunakan kemampuannya secara penuh bagi kemaslahatan manusia, bahkan hak kewarisan dan kepemilikan yang dimiliki perempuanpun tidak diakui adanya. Kondisi tersebut juga terjadi di Jazirah Arab sebelum agama Islam datang. ${ }^{5}$

Kedatangan Islam menyebabkan kedudukan dan martabat perempuan sama dan sejajar dengan kaum pria. Dalam masyarakat Islam, perempuan mempunyai kedudukan penting yang tidak pernah ada sebelumnya. Hal itu disebabkan karena Islam datang dengan membawa prinsip-prinsip persamaan di antara seluruh umat manusia, termasuk persamaan antara lakilaki dengan perempuan. Untuk mewujudkan prinsip-prinsip persamaan tersebut diperlukan pemahaman yang benar tentang hak-hak perempuan yang terdapat dalam al-Qur'an dan al-Hadits serta kesadaran dan komitmen semua pihak untuk memenuhi dan melindungi hak-hak perempuan. Islam datang membawa angin segar bagi kaum perempuan karena wahyu Allah yang disampaikan kepada Nabi Muhammad saw banyak membicarakan tentang kaum perempuan, baik mengenai hak-haknya maupun kewajibannya. Islam sudah hadir di dunia ini lebih dari empat abad yang lalu, tetapi ketentuanketentuan yang ada dalam al-Qur'an dan Hadits sebagai sumber hukum Islam belum terealisasi dengan baik dalam masyarakat Islam, bahkan sampai sekarang masih ada praktik di lingkungan umat Islam yang masih menempatkan perempuan tidak sebagaimana mestinya. Walaupun jumlahnya tidak banyak, tetapi kondisi tersebut dapat menimbulkan pemahaman dalam masyarakat bahwa Islam kurang memperhatikan hak-hak perempuan. Padahal ajaran Islam memberi perhatian yang sangat besar serta memberi kedudukan yang terhormat pada perempuan. Menurut Mahmud Syaltut, yang dikutip oleh Quraish Shihab:

Tabiat kemanusiaan antara laki-laki dengan perempuan hampir dapat (dikatakan) sama, Allah telah menganugerahkan kepada perempuan sebagaimana dianugerahkan kepada laki-laki, kepada merka berdua dianugerahkan Tuhan potensi dan kemampuan yang cukup untuk memikul tanggungjawab dan

5 Haifaa A. Jawad, "Otentisitas Hak-hak Perempuan, Perspektif Islam Atas Kesetaraan Jender", diterjemahkan oleh Anni Hidayatun Noor, Sulhani Hermawan dan H. Badrian, (Yogyakarta: Fajar Pustaka Baru, 2002), hal. 1. 
yang menjadikan kedua jenis kelamin ini dapat melaksanakan aktivitas-aktivitas yang bersifat umum maupun khusus. Karena itu hukum-hukum syari'at meletakkan keduanya dalam satu kerangka, yang ini (laki-laki) dapat menjual, membeli, mengawinkan dan kawin, melanggar dan dihukum, menuntut dan menyaksikan, dan yang itu (perempuan) juga demikian, dapat menjual dan membeli, mengawinkan dan kawin, melanggar dan dihukum serta menuntut dan menyaksikan. ${ }^{6}$

Cukup banyak faktor yang mengaburkan keistimewaan perempuan dan menurunkan kedududukannya, salah satu di antaranya adalah kedangkalan pengetahuan keagamaan dan kesalahan penafsiran teks al-Qur'an dan alHadits, sehingga tidak jarang ajaran Islam dimanfaatkan untuk tujuan yang tidak benar. Dalam ajaran Islam, pada dasarnya semua manusia adalah sama, karena semua adalah hamba Allah. Hanya satu ukuran yang dapat membuat seseorang lebih tinggi derajatnya dari yang lain, yakni tingkat ketaqwaannya. Prinsip ini dengan tegas disebutkan dalam al-Qur'an surat 49 ayat 13 yang artinya lebih kurang sebagai berikut:

Wahai manusia, sesungguhnya Kami telah menciptakan kamu dari seorang laki-laki dan seorang perempuan dan kami telah menjadikan kamu berbangsa-bangsa dan bersuku-suku agar kamu saling berkenalan. Sesungguhnya yang paling mulia (di antara kamu) dalam pandangan Allah adalah yang paling takwa. Sesungguhnya Allah Maha Mengetahui dan Maha Mengenal.

Dari ayat di atas dapat dipahami bahwa Allah menciptakan manusia dengan hak yang sama, baik laki-laki maupun perempuan menurut kodrat dan fitrahnya masing-masing. Kalau ada perbedaan, perbedaan itu akan menimbulkan hak di pihak yang satu dan menambah kewajiban di pihak lain, karena salah satu ciri hukum Islam adalah adil. Dalam hukum Islam kata adil disebutkan lebih dari 1000 kali dalam al-Qur'an, yakni kata terbanyak sesudah Allah dan ilmu pengetahuan. ${ }^{7}$ Hal ini menunjukkan bahwa hukum

- Muhammad Quraish Shihab, "Konsep Wanita Menurut Qur'an, Hadits dan Sumber-sumber Islam", dalam Lies M. Marcoes-Natsir dan Hendrik, "Wanita Islam Indonesia dalam Kajian Tekstual dan Kontektual”, (Jakarta: INIS, 1993), hal. 4.

7 Ahmad M. Saefuddin, "Ekonomi dan Masyarakat dalam Perspektif Islam", (Jakarta: Rajawali, 1987), hal. 68. 
Islam sangat menekankan keadilan diterapkan kepada siapapun, apalagi kepada sesama manusia. Oleh karena itu sangat mustahil bila dalam ajaran Islam terdapat aturan yang bersifat diskriminatif terhadap perempuan. Permasalahannya, keadilan tersebut belum teralisasi dalam masyarakat sebagaimana yang dimaksudkan dalam al-Qur'an dan al-Hadits. Cukup banyak kasus yang menunjukkan hak-hak perempuan tidak terpenuhi dan bahkan kadang kala terjadi pelanggaran terhadap hak-hak merka.

Ajaran Islam yang bersumber dari al-Qur'an dan as-Sunnah banyak membahas masalah-masalah yang berkenaan dengan kehidupan sosial. Salah satu masalah yang menjadi titik perhatian al-Qur'an adalah kaum perempuan. Begitu pentingnya masalah ini, Allah swt mewahyukan suatu surat dalam alQur'an yang diberi nama surat an-Nisa', yang berarti perempuan. Sebagian besar ayat-ayat dalam surat An-Nisa' membicarakan hal-hal yang berhubungan dengan perempuan, terutama yang berkaitan kedudukan, peranan, dan perlindungan hukum terhadap hak-hak perempuan. Di samping dalam surat An-Nisa', masalah-masalah perempuan juga disebutkan dalam beberapa surat, antara lain dalam surah al-Baqarah, Ali Imran, al-Maidah, Yusuf, Maryam, al-A'raf, an-Nur, al-Ahzab, al-Mujadalah, at-Tahrim dan ath-Thalaq. Untuk menjelaskan dan memperkuat ayat-ayat al-Qur'an, Nabi Muhammad saw juga membahas masalah perempuan melalui Sunnah Beliau. Sedangkan dalam Kitab-kitab Fikih hak-hak dan kewajiban perempuan dibahas dalam bab ibadah dan bab-bab mu'amalah. ${ }^{8}$ Hal ini menunjukkan bahwa dalam ajaran Islam, perempuan mendapat perhatian khusus karena perempuan dianggap memiliki kedudukan yang sangat terhormat.

Dalam sejarah Islam cukup banyak perempuan yang ahli di berbagai disiplin ilmu. Sebagai contoh misalnya Khadijah binti Khuwailid (wafat tahun $619 \mathrm{M}$ ). Selain sebagai isteri Rasulullah, beliau juga seorang pedagang ulung pada zamannya; Fatimah binti Rasulullah saw (605 M-633 M), beliau adalah orator ulung dan pernah terjun ke dunia politik dan mencalonkan Ali bin Abi Thalib (suaminya) untuk menjadi khalifah pertama; "Aisyah binti Abu Bakar Ash-Shiddiq (613-678), selain sebagai isteri Rasulullah, Aisyah juga seorang ilmuwan dan politisi. Sebagai ilmuwan, beliau meriwayatkan Hadits sebanyak 2210 buah, dan sebagai politisi, beliau pernah menjadi komandan tertinggi dalam perang Jamal (Perang Unta); Sayyidah, ibu kandung Khalifah al-Muqtadir yang memerintah pada tahun 908-932 M. Beliau mengendalikan pemerintahan dari belakang layar karena putranya alMuqtadir memegang kekuasaan sejak masih kecil. Sayyidah adalah pembuka

${ }^{8}$ Huzaemah T, "Konsep Wanita m enurut Qur'an, Sunnah, dan Fikih", di dalam Lies M. Marcoes-Natsir dan Johan Hendrik Meuleman, "Wanita Islam Indonesia Dalam Kajian Tekstual dan Kontekstual", (Jakarta: INIS, 1993), hal. 19. 
jalan berkuasanya kaum perempuan dalam pemerintahan; Qahramanah, nama aslinya Matsal. Beliau hidup semasa dengan Sayyidah. Qahramanah merupakan hakim perempuan pertama di dunia Islam. Ia menduduki jabatan hakim karena ditunjuk oleh Sayyidah: Walaupun awalnya mendapat tantangan yang berat, tetapi akhirnya hakim Abu al-Hasan mengakuinya sebagai hakim yang ahli di bidangnya; Syajarat Addur, meninggal tahun 648 H/1250 M. Ia adalah penguasa Mesir pada akhir pemerintahan Ayyubiyah pada tahun $647 \mathrm{H}$ sesudah suaminya meninggal dunia.' Di samping namanama yang sudah dikemukakan, masih banyak tokoh-tokoh perempuan berprestasi pada masa lampau.

Adanya tokoh-tokoh perempuan yang dikemukakan menunjukkan bahwa sejak awal Islam sudah cukup banyak perempuan yang berkiprah di dunia ilmu pengetahuan, perdagangan, politik dan bidang-bidang lain. Dengan demikian kian nyata bahwa Islam selalu memberi kesempatan kepada kaum perempuan untuk mengembangkan diri sesuai dengan lapangan yang tersedia dan kemampuan yang merka miliki. Di samping sudah dicontohkan oleh Khadijah dan 'Aisyah, di dalam al-Qur'an juga disebutkan bahwa kedudukan perempuan dalam Islam tidak sebagaimana diduga atau dipraktikkan oleh sebagian masyarakat, karena dalam al-Qur'an terdapat terdapat ayat-ayat memberikan perhatian yang sangat besar dan kedudukan terhormat kepada perempuan. Al-Qur'an berbicara tentang perempuan menyangkut berbagai sisi kehidupan, ada ayat yang membicarakan tentang hak dan kewajiban kaum perempuan, dan ada pula ayat yang menguraikan keistimewaan-keistimewaan tokoh-tokoh perempuan dalam sejarah agama dan kemanusiaan. Mengenai hak-hak perempuan, Allah berfirman dalam surat an-Nisa' ayat 32: "Bagi laki-laki hak/bagian dari apa yang dianugerahkan kepadanya/diusahakannya dan bagi perempuan hak/bagian dari apa yang dianugerahkan kepadanya/diusahakannya".

Kebangkitan Islam menyebabkan kedudukan perempuan didefinisikan ulang secara radikal. Misalnya, "Islam melarang pembunuhan bayi perempuan dan mengembalikan hak-hak lahir bagi perempuan". Dengan demikian Islam telah mengangkat perempuan pada kedudukan sebagai manusia yang berharga dan bermartabat sebagaimana laki-laki. Islam juga telah mengubah mentalitas kaum laki-laki dan perempuan dan kemudian menciptakan suatu bentuk hubungan baru di antara keduanya yang didasarkan pada rasa saling hormat menghormati dan saling pengertian dengan disertai penekanan untuk menjaga dan menghargai perempuan. Posisi kaum perempuan juga diangkat oleh Islam dengan memberikan hak-hak hukum untuk melakukan kontrak (perjanjian), menjalankan bisnis dan

${ }^{9}$ Huzaemah T., Op. Cit., hal. 29-32. 
memiliki barang secara merdeka, tidak tergantung pada suami ataupun keluarga laki-laki merka. ${ }^{10}$ Islam telah menekankan bahwa kaum perempuan yang merupakan bagian dari masyarakat harus diberi kesempatan yang memungkinkan terjadinya pengembangan kemampuan alamiah yang merka miliki, sehingga merka bisa berpartisipasi secara efektif dalam pengembangan masyarakat. Islam telah menekankan bahwa kaum perempuan harus diberi kesempatan untuk mencapai tingkat kemajuan tertinggi dalam berbagai hal termasuk dalam hal material, intelektual dan spiritual merka. ${ }^{11}$

Dalam al-Qur'an surat al-Mudatstsir ayat 38 disebutkan bahwa kaum perempuan mempunyai kedudukannya yang sama dengan kaum laki-laki: "Tiap-tiap diri bertanggungjawab atas apa yang telah yang telah diperbuatnya". Kemudian dalam surat an-Nisa' ayat 124 Allah juga berfirman: "Barang siapa yang mengerjakan amal-amal shalih, baik laki-laki maupun perempuan sedang ia beriman, maka merka itu masuk ke dalam syurga dan merka tidak dianiaya sedikitpun". Dari ayat-ayat tersebut dapat dipahami bahwa Allah tidak membedakan antara laki-laki dengan perempuan khususnya di bidang ibadah seperti shalat, puasa, haji, dan lain-lain. Bahkan dalam hal shalat, puasa dan haji, kaum perempuan ada beberapa keringanan. Sebagai contoh pada saat perempuan sedang menstruasi dan setelah melahirkan selama masih dalam kondisi nifas, ia tidak diwajibkan shalat. Perempuan juga diperbolehkan tidak puasa dalam bulan Ramadlan selama perempuan itu hamil atau menyusui bilamana puasa itu membahayakan kesehatan dirinya atau bayinya walaupun ia wajib mengganti puasa yang ia tinggalkan di lain waktu. Hal ini menunjukkan bahwa dalam Islam walaupun kedudukan perempuan dengan lak-laki sama, namun tetap memperhatikan kondisi masing-masing. Sebagai contoh misalnya dalam keluarga, suami dan isteri mempunyai kedudukan yang seimbang, menurut kodrat dan fitrahnya masing-masing dan menjaga serta memelihara keseimbangan itu agar pergaulan hidup dalam keluarga berkembang dengan baik, bahagia, saling mencintai dan sayang menyayangi. ${ }^{12}$ Masalah keseimbangan antara hak dan kewajiban bagi seorang perempuan tersebut dalam al-Qur'an surat alBaqarah ayat 228 Allah berfirman: “...Dan para wanita mempunyai hak yang seimbang dengan kewajibannya menurut cara yang ma'ruf...”. Dalam Islam

${ }^{10}$ L. Al-Faruqi, Islamic Traditions and Feminist Movement: Confrontation or Cooperation, The Islamic Quarterly, Vol. XXVII, No. 3, 1983, hal. 136. Lihat juga: Haifaa, Op. Cit., hal. 15.

${ }^{11}$ Ibid.

${ }^{12}$ Mohammad Daud Ali dan Habibah Daud, Op. Cit., hal. 61. 
suami adalah mitra (partner=pasangan) isteri, demikian juga sebaliknya. Karena keseimbangan kedudukannya itu, dalam hal-hal tertentu, wewenang, hak dan kewajiban suami isteri adalah sama. Kalau ada perbedaan, perbedaan itu akan menimbulkan hak di pihak yang satu dan menambahkan kewajiban di pihak lain. Kelebihan hak pada suami (seorang laki-laki) karena kedudukannya sebagai kepala keluarga diimbangi dengan tambahan kewajiban untuk menafkahi seluruh anggota keluarga, termasuk isterinya, kendatipun isterinya itu kaya atau mempunyai penghasilan sendiri. ${ }^{13}$

Jika pembahasan yang sudah dikemukakan dikaji lebih dalam tampak jelas bahwa Islam telah memberi kesempatan yang seluas-luasnya kepada kaum perempuan, baik dalam kehidupan keluarga, masyarakat maupun kehidupan politik. Yang menjadi masalah, meskipun sejak zaman Nabi Muhammad perempuan sudah diperbolehkan bekerja dan berkarya, diperkuat lagi dengan ayat-ayat al-Qur'an dan al-Hadits yang membolekan perempuan berkarir, tetapi pemahaman dan praktik yang terjadi di sebagian masyarakat justru sebaliknya, masih banyak perempuan yang keadaannya memprihatinkan, di mana perempuan kadang masih dianggap makhluk yang lemah sehingga keberadaan perempuan seringkali digolongkan sebagai "second class citizen". ${ }^{14}$ Menurut Harkristuti Harkrisnowo, ada beberapa faktor yang menyebabkan kondisi perempuan menuntut keprihatinan semua pihak, yakni: ${ }^{15}$

a. adanya persepsi masyarakat terhadap perempuan yang belum menempatkan perempuan sebagai mitra sejajar dengan lakilaki. Surga ada di telapak kaki Ibu dan perempuan adalah orang yang di "empu" kan lebih banyak dijadikan sebagai slogan yang membuai kaum perempuan merasa ada di atas pedestal yang dibangun laki-laki. Namun dalam praktik keseharian sulit untuk dioperasionalisasikan dan ini terlihat pada berbagai esei yang dikisahkan perempuan terutama merka yang berada dalam strata bawah.

b. ketentuan hukum yang ada belum secara khusus memberikan perlindungan terhadap perempuan. Memang ada ketentuanketentuan hukum umum yang dapat dipergunakan untuk

${ }^{13}$ Ibid.

${ }^{14}$ Harkristuti Harkrisnowo, "Perempuan dan Hak Asasi Manusia dalam Perspektif Yuridis", dalam Nur Iman Subono (ed.), "Negara dan Kekerasan Terhadap Perempuan", (Jakarta: Yayasan Jurnal Perempuan, 2000), hal. 207.

${ }^{15}$ Ibid., hal. 207-208. 
melindungi hak-hak warga masyarakat. Namun demikian, kaum perempuan yang secara kodrati lebih lemah dari lakilaki secara fisik, bukan hanya tidak tidak memperoleh hak-hak khusus atau privileges (kecuali beberapa hak yang dikaitkan dengan hukum perburuhan), bahkan dalam banyak kasus sangat kentara justru adanya diskriminasi terhadap perempuan.

c. mayoritas perempuan belum mengetahui akan hak-hak merka. Kalaupun komunitas perempuan tahu, belum banyak yang menuntut pemenuhan hak-hak tersebut pada negara. Tiada atau langkanya tuntutan semacam ini dapat disebabkan banyak faktor. Bisa jadi karena ketidak pedulian, karena merasa akan berakibat kesia-siaan atau karena takut mengalami retaliasi, baik secara langsung maupun tidak langsung, baik dari lingkungan yang terdekat, lingkungan bekerja maupun lingkungan warga di mana merka tinggal.

Kondisi-kondisi tersebut menurut Harkristuti Harkrisnowo, pada akhirnya menggiring perempuan untuk bersikap konformis, sesuai dengan apa yang dituntut dan dirumuskan masyarakat (laki-laki?). Sebagai suatu perubahan sikap atau tingkah laku, konformitas yang terjadi lebih banyak diakibatkan oleh adanya tekanan (pressure), baik yang nyata maupun tidak. Tekanan itu sendiri berasal dari individu, kelompok maupun masyarakat. ${ }^{16}$ Meskipun kasus yang dikemukakan oleh Harkristuti adalah kasus Indonesia, namun menurut penulis di beberapa negara Islam atau negara yang mayoritas penduduknya beragama Islam permasalahannya hampir sama dengan Indonesia.

Keadaan demikian tentu kurang baik dan harus diperhatikan, karena setiap perempuan, siapapun dan di manapun dia berada sangat mendambakan keadilan. Agar keadilan benar-benar tercapai, maka setiap perempuan harus memahami hak-haknya. Untuk itu, diharapkan ia berusaha meningkatkan pengetahuannya sehingga ia mampu memperjuangkan hak-haknya yang selama ini mungkin terabaikan. Untuk meningkatkan pengetahuan tentang hak-hak perempuan bagi kaum perempuan bukanlah hal yang mudah terutama bagi merka yang tinggal di pedesaan yang pendidikannya relatif terbatas. Oleh karena itu sosialisasi hak-hak perempuan di lingkungan kaum perempuan khususnya merka yang pendidikannya rendah dan tinggal di pedesaan mutlak dilakukan. Sosialisasi tersebut dapat dilakukan oleh pemerintah, masyarakat ataupun oleh masing-masing individu yang sudah 
lebih dahulu memahaminya. Karena dalam hukum Islam, hak-hak perempuan sebenarnya sudah jelas disebutkan dalam al-Qur'an, as-Hadits, kitab-kitab Fikih dan buku-buku lainnya. Hal ini berarti bahwa merka yang sudah memahami isi al-Qur'an, logikanya yang bersangkutan sudah memahami hak-hak perempuan dalam hukum Islam.

\section{Hak-hak Perempuan Menurut Hukum Islam}

Islam datang antara lain untuk melarang dan melenyapkan kedzaliman terhadap perempuan, artinya pada saat Allah mengangkat Muhammad sebagai Rasul, Allah membebaskan kaum perempuan secara benar dan rasional. Allah memberikan hak-hak perempuan secara sempurna sesuai dengan fitrah dan kodratnya. Perempuan mempunyai hak dan kewajiban yang sama dengan laki-laki, kecuali dalam beberapa hal yang harus disesuaikan dengan nalurinya. ${ }^{17}$ Sayangnya sampai sekarang masih ada sebagian orang yang membagi perempuan dan laki-laki hanya berdasarkan budaya atau pemikiran masyarakat di suatu tempat pada waktu tertentu.

Dalam masyarakat, pembagian jenis kelamin antara lelaki dan perempuan bukan hanya secara biologis saja, tetapi lelaki dan perempuan juga dilihat dari segi prilaku, jenis pekerjaan, sifat-sifat yang umumnya dilakukan oleh lelaki dan perempuan serta selera, model dan berbagai kebiasaan. Pembagian jenis kelamin yang kedua ini tidak berdasarkan biologis melainkan suatu pembagian lelaki dan perempuan menurut kebiasaan, adat atau kebudayaan suatu masyarakat. Jadi ada pembedaan dan pembagian jenis kelamin secara biologis, dan ada juga pembedaan dan pembagian lelaki dan perempuan dilihat dari segi sosial budaya yang dalam kepustakaan disebut dengan jender. Dari segi bahasa, jender berasal dari bahasa Inggeris "gender" yang berarti jenis kelamin. ${ }^{18}$ Sedangkan dalam Webster's New World Dictionary, jender diartikan sebagai "perbedaan yang tampak antara laki-laki dan perempuan dilihat dari segi nilai dan tingkah laku". ${ }^{19}$ Dalam Women's Studies Encyclopedia disebutkan bahwa jender adalah suatu konsep kultural yang berupaya membuat pembedaan dalam hal

${ }^{17}$ Muhammad al-Hamid, "Islam Rahmat bagi Wanita", diterjemahkan oleh Kathur Suhardi, (Surabaya: Risalah Gusti, 1992), hal. 2.

${ }^{18}$ John M. Echols dan Hasan Shadily, "Kamus Inggeris Indonesia", Cetakan XII, (Jakarta: Gramedia, 1983), hal. 265.

19 Victoria Neufeld (ed.), "Webster's New World Dictionary", (New York: Webster's New World Clevenland, 1984), hal. 561. 
peran, perilaku, mentalitas dan karakteristik emosional antara laki-laki dan perempuan yang berkembang dalam masyarakat. ${ }^{20}$ Sedangkan menurut Nasaruddin Umar, jender adalah suatu konsep yang digunakan untuk mengidentifikasi perbedaan laki-laki dan perempuan dilihat dari segi sosialbudaya. Jender dalam arti ini mendefinisikan laki-laki dan perempuan dari sudut non-biologis. ${ }^{21}$ Perbedaan dan pembagian ini jelas hanya berdasarkan sifat, peran dan watak yang dibuat oleh masyarakat di suatu tempat pada suatu masa. Oleh karena itu jender bukanlah kodrat, atau ketentuan Tuhan. Misalnya keyakinan bahwa lelaki itu kuat, kasar dan rasional, sedangkan perempuan lemah lembut dan emosional. Pembagian peran, sifat maupun watak perempuan dan lelaki itu dapat dipertukarkan dan berubah dari masa ke masa, dari satu tempat ke tempat lain dan satu adat satu ke adat yang lain dan dari kelas orang kaya ke kelas orang miskin. Oleh karena itu, jender sangat berkaitan dengan proses keyakinan bagaimana seharusnya lelaki dan perempuan diharapkan berpikir dan bertindak sesuai dengan ketentuan sosial dan budaya di mana merka berada. Dengan demikian pembedaan tersebut ditentukan oleh aturan masyarakat dan bukan karena perbedaan biologi, sehingga pembagian jender tersebut juga berbeda-beda antara satu bangsa dengan bangsa yang lain dalam kurun waktu yang berbeda. ${ }^{22}$

Diskriminasi jender pada dasarnya adalah setiap pembedaan, penyingkiran atau pembatasan atau sebaliknya yakni pilih kasih yang dilakukan seseorang karena alasan jender, sehingga mengakibatkan penolakan pengakuan dan kebahagiaan serta penolakan keterlibatan, dan pelanggaran atas pengakuan hak asasinya dan persamaan antara lelaki dan perempuan, serta hak dasarnya dalam bidang politik, ekonomi, sosial serta budaya. Diskriminasi bentuknya bermacam-macam, diantaranya ${ }^{23}$ :

a. Diskriminasi Langsung, terjadi jika seseorang diperlakukan berbeda secara terbuka dan langsung dalam suatu ketentuan atau aturan. Diskriminasi dalam bentuk ini dengan jelas menyingkirkan kaum perempuan, misalnya: "Syarat nahkoda

${ }^{20}$ Helen Tierney (ed.), "Women's Study Encyclopedia", Vol. I (New York: Green Wood Press), hal. 153.

${ }^{21}$ Nasaruddin Umar, “Argumen Kesetaraan Jender Perspektif al-Qur’an”, (Jakarta: Paramadina, 2001), hal. 33-35.

${ }^{22}$ Uswatun Hasanah dan Mutiara Hikmah, "Hak-hak Perempuan", (Depok: Sentra HAM FHUI-BAKESBANG DKI Jaya, 2003), hal. 2

${ }^{23}$ Ibid., hal. 2-3. Lihat juga: International Labour Organization, "Apa Itu Gender?”, (Jakarta: ILO, 1997 ), hal. 24. 
kapal adalah laki-laki; Perempuan jangan diberi tugas bagian mesin, karena tidak cocok dengan sifat merka".

b. Diskriminasi secara tidak langsung, terjadi jika suatu peraturan atau kebijakan tidak membedakan antara laki-laki dan perempuan. Dalam peraturan, tidak terlihat adanya diskriminasi terhadap perempuan karena bersifat netral, tetapi jika peraturan itu diterapkan akan menguntungkan kelompok atau jenis kelamin tertentu saja. Misalnya, untuk menjadi satpam pabrik disyaratkan hanya bagi merka yang memiliki tinggi badan $170 \mathrm{~cm}$ saja; aturan ini dapat menyingkirkan perempuan atau hanya sedikit perempuan yang mendapat posisi itu.

c. Diskriminasi sistematik, terjadi sebagai hasil ketidak adilan yang berakar dalam sejarah, adat, norma atau struktur masyarakat yang mewariskan keadaan diskriminatif. Diskriminasi dalam bentuk ini terjadi mungkin tidak sengaja dan tanpa disadari oleh pelakunya, tetapi berakibat buruk pada korbannya. Misalnya: Perempuan itu tugasnya hanyalah mengurus rumah tangga, sehingga wanita tidak pantas kalau bekerja apalagi sampai malam hari.

Diskriminasi dalam bentuk ketiga ini sudah mendarah daging dalam masyarakat sehingga untuk masyarakat tertentu sangat sulit untuk merubahnya. Bahkan tidak sedikit perempuan yang memahami hak-hak perempuan, tetapi di saat ia berhadapan dengan adat dan budaya yang dianut keluarga atau komunitasnya, ia dapat menerima keadaan tersebut dengan berbagai pertimbangan, seperti jangan sampai menimbulkan konflik. Keadaan ini menurutnya mungkin tidak ada masalah, tetapi sebenarnya apa yang dia lakukan akan memperkuat ketidakadilan jender dalam masyarakat, dan sebagai akibat selanjutnya akan memperlemah kaum perempuan.

Sampai saat ini ketidakadilan jender masih juga terjadi dalam masyarakat, bahkan bentuknya bermacam-macam, diantaranya: ${ }^{24}$

1. Penomorduaan (Subordinasi), yang dimaksud disini adalah proses yang berhubungan dengan masalah politik dan proses pengambilan keputusan serta pengendali kekuasaan. Meskipun jumlah kaum perempuan saat ini lebih banyak dari laki-laki, namun posisi merka di bidang politik ditentukan dan dipimpin oleh kaum lelaki.

${ }^{24}$ Ibid., hal. 26. Lihat juga Uswatun Hasanah dan Mutiara Hikmah. Op. Cit., hal. 3. 
2. Pemiskinan (Marginalisasi), banyak terjadi dalam budaya, birokrasi, di pabrik bahkan dalam program pembangunan. Sebagai contoh misalnya adanya perbedaan upah di pabrik antara laki-laki dengan perempuan dengan alasan laki-laki lebih kuat dari perempuan.

3. Anggapan negatif (Stereotip) adalah satu bentuk diskriminasi dengan cara memberi "label" yang memojokkan kaum perempuan dan berakibat negatif terhadap merka.

4. Beban Kerja (Burden). Pada umumnya rumah tangga, beberapa jenis kegiatan yang dilakukan oleh lelaki dan beberapa kegiatan lain dilakukan oleh perempuan, Observasi yang pernah dilakukan menunjukkan bahwa perempuan mengerjakan hampir $90 \%$ dari pekerjaan rumah tangga. Terlebih-lebih bagi perempuan yang berkarir (bekerja di luar rumah), karena selain bekerja di tempat kerja merka juga masih harus mengerjakan pekerjaan rumah tangga.

5. Kekerasan (Violence). Banyak bentuk kekerasan terjadi pada kaum perempuan. Pertama yang bersifat fisik, seperti pemerkosaan, incest, pemukulan dan penyiksaan, dan lain-lain. Kedua yang bersifat nonfisik seperti pelecehan seksual, membuat secara emosional tergantung, dan lain-lain.

6. Sosialisasi keyakinan jender, mengakibatkan tersosialisasinya citra posisi, kodrat dan penerimaan nasib perempuan yang ada.

Ketidak adilan jender tersebut sangat merugikan kaum perempuan. Padahal perlindungan hak asasi manusia pada dasarnya dimaksudkan untuk melindungi hak-hak seluruh manusia baik laki-laki maupun perempuan. Tuhan menciptakan perempuan dan laki-laki dalam posisi setara. Oleh karena itu, hak-hak perempuan adalah hak-hak yang fundamental manusia yang merupakan karunia Tuhan. Dalam Pasal 2 Deklarasi Universal tentang Hak Asasi manusia PBB disebutkan bahwa:

Setiap orang berhak atas semua hak dan kebebasan yang dinyatakan dalam deklarasi ini, dengan tanpa pembedaan apapun seperti ras, warna kulit, jenis kelamin, bahasa, agama, pendapat politik atau pendapat lain, asal-usul kebangsaan atau sosial, harta milik, status kelahiran atau status lain. Selanjutnya tidak boleh dilakukan pembedaan atas dasar status politik, status yurisdiksi atau status internasional negara atau wilayah tempat seseorang termasuk di dalamnya, apakah wilayah itu merdeka, perwalian, tidak berpemerintahan sendiri atau di bawah pembatasan kedaulatan lain apapun. 
Prinsip non diskriminasi adalah konsep sentral dalam hak asasi manusia. Diskriminasi terhadap perempuan berarti pembedaan, pengesampingan atau pelarangan apapun, yang dibuat atas dasar jenis kelamin yang mempunyai akibat atau tujuan mengurangi atau meniadakan pengakuan, perolehan atau pelaksanaan oleh perempuan dengan mengabaikan status perkawinan merka atas dasar persamaan laki-laki dan perempuan, atas dasar hak asasi manusia dan kebebasan-kebebasan dasar dibidang politik, ekonomi, sosial budaya, sipil atau bidang lain apapun.

Pada Konferensi Hak Asasi Manusia di Wina tahun 1993, pemerintahpemerintah dunia menegaskan kembali bahwa hak asasi manusia adalah hak yang dibawa sejak lahir dan melekat pada diri manusia dan bahwa perlindungan terhadap HAM adalah tanggung jawab pemerintah sepenuhnya. Dalam Konferensi Hak Asasi Manusia dunia 1993 itu juga mengakui secara khusus hak-hak perempuan dan merupakan kewajiban negara untuk melindungi dan menegakkan hak-hak itu, termasuk hak bebas dari kekerasan.

Pada tahun 1967 Perserikatan Bangsa-Bangsa telah mengeluarkan Deklarasi mengenai Penghapusan Diskriminasi terhadap perempuan. Deklarasi tersebut memuat hak dan kewajiban berdasarkan persamaan hak dengan laki-laki dan menyatakan agar diambil langkah-langkah seperlunya untuk menjamin pelaksanaan Deklarasi tersebut. Oleh karena Deklarasi itu tidak bersifat mengikat, maka Komisi Perserikatan Bangsa-Bangsa tentang Kedudukan Perempuan berdasarkan Deklarasi tersebut menyusun rancangan Konvensi tentang Penghapusan Segala Bentuk Diskriminasi terhadap Perempuan. Pada tanggal 18 Desember Tahun 1979 Majelis Umum Perserikatan Bangsa-Bangsa telah menyetujui Konvensi tersebut.

Di samping beberapa instrumen yang sudah disebutkan, masih cukup banyak instrumen hukum internasional yang berkenaan dengan HAM yang bermuatan perlindungan terhadap hak-hak perempuan, antara lain: Deklarasi tentang Penghapusan Tindak Kekerasan terhadap Perempuan (1994); Kovenan Internasional tentang Hak-hak Politik dan Sipil; Konvensi Internasional tentang Hak-hak Politik Perempuan; Kovenan Internasional tentang Hak-hak Ekonomi, Sosial dan Budaya; Deklarasi Beijing;; Konvensi tentang Kewarganegaraan Perempuan; Konvensi Melawan Diskriminasi Dalam Pendidikan; Konvensi Internasional tentang Organisasi Buruh.

Berdasarkan instrumen-instrumen yang sudah dikemukakan, hak-hak yang harus dipenuhi oleh setiap orang termasuk hak bagi seorang perempuan, antara lain adalah sebagai berikut: (1) hak untuk hidup serta mempertahankan hidup dan kehidupannya; (2) hak untuk membentuk keluarga dan melanjutkan keturunan melalui perkawinan yang sah; (3) hak anak atas kelangsungan hidup, tumbuh dan berkembang serta atas perlindungan dari kekerasan dan diskriminasi; (4) hak untuk 
mengembangkan diri melalui pemenuhan kebutuhan dasar, hak atas pendidikan \& memperoleh manfaat dari IPTEK; (5) hak untuk memperjuangkan haknya secara kolektif untuk membangun bangsa; (6) hak atas pengakuan, jaminan, perlindungan dan kepastian hukum; (7) hak untuk diperlakukan sama di hadapan hukum; (8) hak untuk bekerja dan mendapat imbalan yang layak; (9) hak dalam pemerintahan; (10) hak atas status kewarganegaraan; (11) hak untuk beragama dan beribadat; (12) hak untuk memilih pekerjaan; (13) hak untuk memilih kewarganegaraan; (14) hak untuk memilih tempat tinggal di wilayah negara dan meninggalkannya serta kembali ke negaranya; (15) hak atas kebebasan meyakini kepercayaannya, menyatakan pikiran dan sikap sesuai dengan hati nurani; (16) hak untuk berkomunikasi dan memperoleh informasi, termasuk mencari, memperoleh, memiliki, menyimpan, mengolah dan menyampaikan informasi melalui sarana apapun; (17) hak atas perlindungan diri pribadi dan keluarganya, kehormatan, martabat dan harta benda yang dibawah kekuasaannya; (18) hak atas rasa aman dan perlindunagn dari ancaman ketakutan untuk berbuat atau tidak berbuat sesuatu yang merupakan hak asasi; (19) hak untuk bebas dari penyiksaan atau perlakuan yang merendahkan derajat martabat manusia; (20) hak untuk hidup sejahtera lahir dan batin; (21) hak atas keadilan dan persamaan; (22) hak atas jaminan sosial; (23) hak untuk mempunyai hak milik pribadi; (24) hak-hak yang tidak dapat dikurangi dalam keadaan apapun (non-derogable rights) mencakup: (a) untuk hidup; (b) hak untuk tidak disiksa; (c) hak kemerdekaan pikian dan hati nurani; (d) hak beragama; (e) hak untuk tidak diperbudak; (f) hak untuk diakui sebagai pribadi di hadapan hukum; (g) hak untuk tidak dituntut berdasar hukum yag berlaku surut; dan (25) hak untuk bebas dari perlakuan diskriminatif.

Prinsi-prinsip HAM yang tercantum dalam berbagai instrumen tersebut sebenarnya sudah dilukiskan dalam berbagai agama, termasuk agama Islam. Agama Islam memerintahkan umat manusia untuk mengikuti bimbingan Allah selama hidupnya. Seluruh bumi ini menurut ajaran Islam merupakan tempat di mana manusia harus bertindak dalam setiap aspeknya untuk mengabdi hanya kepada Allah. Tujuan eksistensi manusia di dunia menurut Islam adalah semata-mata untuk beribadah kepada Allah.

Dari pernyataan di atas ada sebagian orang yang menyangka bahwa menurut hukum Islam manusia tidak memiliki hak-hak selain hanya kewajiban-kewajiban. Pandangan demikian, jelas tidak benar. Menurut A.K. Brohi, dalam totalitas Islam, kewajiban manusia pada Allah mencakup juga kewajibannya kepada setiap individu yang lain. Maka secara paradoks hakhak setiap individu itu dilindungi. oleh segala kewajiban di bawah hukum Ilahi. Ada perbedaan prinsip antara hak asasi manusia dilihat dari sudut padangan Barat dan Islam. Hak asasi manusia menurut pemikiran Barat 
semata-mata bersifat antroposentris, artinya, segala sesuatu berpusat kepada manusia. Sebaliknya, hak asasi manusia dilihat dari sudut pandangan Islam bersifat teosentris, artinya, segala sesuatu berpusat kepada Tuhan. Dengan demikian Tuhan sangat dipentingkan. Dalam hubungan ini A.K. Brohi menyatakan: "Berbeda dengan pendekatan Barat, strategi Islam sangat mementingkan penghargaan kepada hak-hak asasi dan kemerdekaan dasar manusia sebagai sebuah aspek kualitas dari kesadaran keagamaan yang terpatri di dalam hati, pikiran dan jiwa penganut-penganutnya. Perspektif Islam sungguh-sungguh bersifat teosentris. ${ }^{25}$

Pemikiran Barat menempatkan manusia pada posisi bahwa manusialah yang menjadi tolok ukur segala sesuatu, maka di dalam Islam melalui firman-Nya, Allahlah yang menjadi tolok ukur segala sesuatu, sedangkan manusia adalah ciptaan Allah untuk mengabdi kepada-Nya. Di sinilah letak perbedaan yang fundamental antara hak asasi manusia menurut pola pemikiran Barat dengan hak asasi manusia menurut pola pemikiran Islam. Makna teosentris bagi orang Islam adalah manusia pertama-tama harus meyakini ajaran pokok Islam yang dirumuskan dalam dua kalimat syahadat yakni pengakuan tiada Tuhan selain Allah dan Muhammad adalah utusanNya. Barulah setelah itu manusia melakukan perbuatan-perbuatan yang baik menurut isi keyakinannya itu. ${ }^{26}$

Dari uraian tersebut di atas, sepintas lalu nampak bahwa manusia hanya mempunyai kewajiban-kewajiban kepada Allah karena ia harus mematuhi hukum-Nya. Namun secara paradoks, di dalam tugas-tugas inilah terletak semua hak dan kemerdekaannya. Menurut ajaran Islam, manusia mengakui hak-hak dari manusia lain, karena hal ini merupakan sebuah kewajiban yang dibebankan oleh hukum agama untuk mematuhi. ${ }^{27}$ Oleh karena itu, hak asasi manusia dalam Islam tidak semata-mata menekankan kepada hak asasi manusia saja, akan tetapi hak-hak itu dilandasi kewajiban asasi manusia untuk mengabdi kepada Allah sebagai Penciptanya.

Petunjuk Ilahi yang berisikan hak dan kewajiban tersebut telah disampaikan kepada umat manusia semenjak manusia itu ada. Diutusnya manusia pertama (Adam) ke dunia mengindikasikan bahwa Allah telah memberikan petunjuk kepada manusia. Kemudian ketika umat manusia menjadi lupa akan petunjuk tersebut, Allah mengutus Nabi dan Rasul-Nya untuk mengingatkan merka akan keberadaannya. Nabi Muhammad saw

25 Brohi, A. K., "Islam dan Hak-hak Asasi Manusia", dalam Altaf Gauhar, "Tantangan Islam", diterjemahkan oleh Anas mahyuddin, (Bandung: Pustaka, 1982), hal. 198.

\footnotetext{
${ }^{26}$ Mohammad Daud Ali dan Habibah Daud, Op. Cit., hal. 304.

${ }^{27}$ Altaf Gauhar, Op.Cit., hal. 204.
} 
diutus bagi umat manusia sebagai Nabi terakhir untuk menyampaikan dan memberikan teladan kehidupan yang sempurna kepada umat manusia seluruh zaman sesuai dengan jalan Allah. Hal ini menunjukkan bahwa menurut pandangan Islam, konsep HAM bukanlah hasil evolusi dari pemikiran manusia, namun merupakan hasil dari wahyu Ilahi yang telah diturunkan melalui para nabi Nabi dan Rasul dari sejak permulaan eksistensi umat manusia di atas bumi. Kewajiban yang diperintahkan kepada umat manusia dapat dibagi ke dalam dua kategori, yaitu huququllah dan huququl 'ibad. Huququllah (hak-hak Allah) adalah kewajiban-kewajiban manusia terhadap Allah swt yang diwujudkan dalam berbagai ritual ibadah, sedangkan huququl'ibad (hak-hak manusia) merupakan kewajiban-kewajiban manusia terhadap sesamanya dan terhadap makhluk-makhluk Allah lainnya. Hak-hak Allah tidak berarti bahwa hak-hak yang diminta oleh Allah karena bermanfaat bagi Allah, karena hak-hak Allah bersesuaian dengan hak-hak makhluk-Nya. ${ }^{28}$

Aspek khas dalam konsep HAM Islam adalah tidak adanya orang lain yang dapat memaafkan pelanggaran hak-hak jika pelanggaran itu terjadi atas seseorang yang harus dipenuhi haknya. Bahkan suatu negara pun tidak dapat memaafkan pelanggaran hak-hak yang dimiliki oleh seseorang. Negara harus memberi hukuman kepada pelanggar HAM dan memberi bantuan kepada pihak yang dilanggar HAM-nya, kecuali pihak yang dilanggar HAMnya telah memaafkan pelanggar HAM tersebut. Di dalam hukum Islam yang terdapat di dalam al-Qur'an, segala persoalan kehidupan dan berbagai penyelesaiannya sudah diatur oleh Allah, bahkan berbagai Hadits Nabi memperjelas firman Allah, agar manusia meningkatkan ketaqwaannya dan menyelesaikan segala persoalan berdasarkan al-Qur'an dan al-Hadits.

Dalam rangka memperingati abad ke-15 Hijriyah., pada tanggal 21 Dzulkaidah atau 19 September 1981 para ahli hukum Islam mengemukakan Universal Islamic Declaration of Human Rights yang diangkat dari al-Qur'an dan Sunnah Nabi Muhammad saw. Pernyataan HAM menurut hukum Islam ini terdiri XXIII Bab dan 63 Pasal yang meliputi seluruh aspek hidup dan kehidupan manusia. Beberapa hal pokok yang dimuat di dalamnya adalah: (1) hak untuk hidup; (2) hak untuk mendapat kebebasan; (3) hak atas persamaan dan kedudukan; (4) hak untuk mendapat keadilan; (5) hak untuk mendapatkan perlindungan terhadap penyalahgunaan kekuasaan; (6) hak untuk mendapat perlindungan atas kehormatan dan nama baik; (7) hak untuk bebas berpikir dan berbicara; (9) hak untuk bebas memilih agam; (10) hak

${ }^{28}$ Syekh Syaukat Hussain, "Hak Asasi Manusia dalam Islam", diterjemahkan oleh Abdul Rochim, (Jakarta: Gema Insani Press, 1996), hal. 54. 
untuk bebas berkumpul dan berorganisasi; (11) hak untuk mengatur tata kehidupan ekonomi; (12) hak atas jaminan sosial; (13) hak untuk bebas mempunyai keluarga dan segala sesuatu yang berkaitan dengannya; (14) hakhak bagi wanita dalam kehidupan rumah tangga (dan masyarakat); (15) hak untuk mendapatkan pendidikan, dan sebagainya, seluruhnya 23 topik. ${ }^{29} \mathrm{Di}$ samping itu negara-negara Islam yang tergabung dalam The Organization of The Islamic Coference (OIC/OKI), pada tanggal 5 Agustus 1990 juga mengeluarkan deklarasi tentang kemanusiaan sesuai dengan syari'at Islam, dan berlandaskan al-Qur'an dan as-Sunnah. Konsepsi hak asasi manusia negara-negara OKI itu disebut dengan Deklarasi Cairo. Disebut demikian karena Deklarasi itu lahir di Cairo, 5 Agustus 1990. Cairo Declaration berisi 25 Pasal tentang hak asasi manusia berdasarkan al-Qur'an dan as-Sunnah, yang dalam penerapan dan realitasnya memiliki beberapa persamaan dengan The Universal Declaration of Human Rights.

Prinsip-prinsip HAM yang tercantum dalam Universal Declaration of Human Rights sebenarnya sudah dilukiskan dalam berbagai ayat al-Qur'an, beberapa di antaranya adalah: ${ }^{30}$

a. Martabat manusia, antara lain disebutkan dalam al-Qur'an, surat 17: 33, yang artinya: "Dan janganlah kamu membunuh jiwa yang diharamkan Allah, melainkan dengan suatu (alasan yang benar). Dan barang siapa dibunuh secara dzalim, maka sesungguhnya Kami telah memberi kekuasaan (ahli waris yang terbunuh atau penguasa untuk menuntut qishas atau diat) kepada ahli warisnya, tetapi janganlah ahli waris itu melampaui batas dalam membunuh. Sesungguhnya ia adalah orang yang mendapat pertolongan.

b. Prinsip persamaan. Prinsip persamaan ini dengan tegas digariskan oleh Allah dalam surat al-Ahqaf ayat 19 yang artinya lebih kurang sebagai berikut: "Dan bagi masingmasing merka derajat menurut apa yang telah merka kerjakan dan agar Allah mencukupkan bagi merka (balasan) pekerjaanpekerjaan merka sedang merka tiadak dirugikan." Prinsip persamaan ini juga disebutkan dalam surat al-Hujurat ayat 13 . Dari ayat-ayat yang disebutkan dalam al-Qur'an dapat ditarik kesimpulan bahwa Allah menciptakan manusia dengan hak

${ }^{29}$ Mohammad Daud Ali dan Habibah Daud, Op. Cit., hal. 317.

${ }^{30}$ Ibid., hal. 316. 
persamaan sesama manusia, baik sebagai perseorangan maupun sebagai bangsa. ${ }^{31}$

c. Prinsip kebebasan menyatakan pendapat. Sesuai dengan fitrah kejadiannya, manusia diciptakan Allah dengan berbagai alat kelengkapan yang berupa akal, budi dan perasaan. Dengan berbagai alat kelengkapan tersebut manusia dilahirkan di bumi penuh dengan kebebasan, dan karenanya manusia memiliki pilihan sendiri dalam perilakunya sehingga ia bisa melakukan tindakan apapun yang ia sukai. Akan tetapi jika dipandang dari segi lain akan terlihat bahwa Allah sebagai Pencipta manusia yang penuh kasih sayang, pasti Allah tidak akan membiarkan ciptaannya yakni manusia berperilaku bebas tanpa batas. Sebab, jika manusia berbuat sesuai dengan kehendaknya sendiri tanpa batas, dia akan menghancurkan dirinya sendiri. Berkenaan dengan itu sejak Nabi Adam as sampai dengan N. Muhammad saw Allah selalu memberi petunjuk kepada umat manusia bagaimana seharusnya dia berperilaku. Dalam ajaran Islam kebebasan yang diberikan kepada manusia adalah kebebasan yang dipimpin dan dibatasi wahyu Allah. Oleh karena itu prinsip kebebasan menyatakan pendapat mengandung makna bahwa manusia wajib menggunakan akal pikirannya secara bertanggungjawab. Akal pikiran yang sehat dan membuahkan pemikiran-pemikiran yang sehat dalam makna selalu dilandasi atau tidak bertentangan dengan al-Qur'an dan al-Hadits.

d. Prinsip kebebasan beragama. Dalam al-Qur'an dengan tegas digariskan suatu prinsip yang berbunyi, "Tidak (boleh) ada paksaan di dalam beragama" (Q.s. 2:256). Prinsip ini mengandung makna bahwa manusia sepenuhnya mempunyai kebebasan untuk menganut suatu keyakinan atau akidah agama yang disenanginya. Manusia yang sudah dilengkapi dengan akal, budi, dan perasaan, diharapkan mampu membedakan mana jalan yang lurus dan mana jalan yang sesat. Jalan mana yang akan dipilih sepenuhnya bebas ditentukan manusia, tetapi Allah sudah memberi peringatan segala resiko dan konsekuensinya setiap jalan yang ditempuh di dunia ini.

${ }^{31}$ Marcel A. Boisard, "Humanisme dalam Islam", diterjemahkan ole H.M. Rasjidi, (Jakarta: Bulan Bintang, 1980), hal. 115. 
e. hak atas jaminan sosial. Sejak lebih empat belas abad yang lalu agama Islam telah menggariskan bahwa di dalam harta orang kaya ada hak orang miskin dan merka yang memerlukan. Hal ini sesuai dengan firman Allah dalam surat adz-Dzariyat ayat 19, yang artinya: "Dan pada harta-harta merka ada hak untuk orang miskin yang meminta dan orang miskin yang tidak mendapat bahagian." Ayat tersebut menunjukkan bahwa kekayaan yang dimiliki seseorang tidaklah sepenuhnya miliknya. Sekurang-kurang $2.5 \%$ dari harta kekayaan yang memenuhi syarat wajib dikeluarkan zakatnya. Tujuan zakat antara lain adalah untuk melenyapkan kemiskinan dan menciptakan pemerataan pendapatan serta mewujudkan keadilan sosial.

f. Hak atas harta benda. Dalam hukum Islam, hak milik seseorang dijunjung tinggi. Sesuai dengan martabat manusia, jaminan sosial dan perlindungan terhadap hak milik seseorang merupakan kewajiban penguasa. Oleh karena itu, siapapun juga termasuk penguasa sekalipun, tidak diperbolehkan merampas hak milik orang lain, kecuali untuk kepentingan umum, menurut tatacara yang telah ditentukan terlebih dahulu.

Pada prinsipnya dalam Islam hak-hak perempuan tidak berbeda dengan hak laki-laki. Sebagai contoh berikut penulis paparkan beberapa hak perempuan yang terdapat ajaran Islam yang bersumber pada al-Qur'an maupun Hadits.

a. Hak-hak ekonomi, yang meliputi hak pemilikan dan hak waris.

Di sepanjang sejarah sebelum Islam datang, perempuan tidak menikmati hak untuk memiliki, bahkan kadang kala dianggap barang yang bisa dimiliki. Dalam kasus-kasus tertentu di saat perempuan dianggap sebagai pemilik, iapun tidak dapat menikmatinya. Islam mengakui kemerdekaan perempuan dalam pemilikan dan berhak memanfaatkan dan menikmati harta yang dimilikinya itu sebagaimana kaum laki-laki. Dalam hukum Islam, perempuan juga mendapat warisan. Walaupun bagian anak perempuan hanya separuh dari bagian anak laki-laki, namun menurut Allamah Thabathaba'i, jumlah pembagian warisan tersebut ada filosofinya. Dalam hal ini Thabathaba'i menyatakan bahwa separuh dari bagian laki-laki secara alamiah akan dikeluarkan untuk biaya pemeliharaan dan perawatan (nafakah) dan biaya pengeluaran perempuan, walaupun laki-laki 
mendapat bagian dua kali lipat bagian perempuan pada akhirnya sebagian juga untuk perempuan. ${ }^{32}$

b. Hak-hak keluarga. Dalam Islam perempuan memiliki hak untuk memilih pasangan merka. Hal ini menunjukkan kemerdekaan pribadi merka, yang telah dirampas di sepanjang sejarah sebelum Islam datang. Ketetapan dan kebebasan ini dapat mengokohkan keluarga dalam masyarakat.

c. Hak-hak sosial. Islam menempatkan perempuan sama dengan lakilaki dalam semua hak sosial. Hak sosial ini antara lain meliputi hak untuk beramar ma'ruf nahi munkar, ikut serta dalam penentuan dan pelayanan sosial, bekerja, meningkatkan profesi, berpartisipasi dalam organisasi sosial dan keagamaan, dan lain-lain.

d. Hak Perempuan di luar rumah. Dalam al-Qur'an surat al-Ahzab ayat 33 memang disebutkan "Dan hendaklah kamu tetap di rumah dan janganlah kamu berhias dan bertingkah laku seperti orang Jahiliyyah dahulu...". Hal ini tidak berarti bahwa perempuan tidak boleh keluar rumah. Pemahaman ini dibuktikan banyaknya perempuanperempuan muslimah pada masa Rasulullah dan masa sahabat yang terlibat dalam kegiatan di luar rumah seperti Ummu Salamah, Safiyyah, Laila al-Ghaffariyah (merka tercatat sebagai tokoh-tokoh yang terlibat dalam peperangan), kemudian Ummu Salim binti Malhan sebagai perias pengantin, Siti Khadijah sendiri sebagai pedagang yang sukses, Asy-Syifa', ditugaskan oleh Khalifah Umar r.a. sebagai petugas yang menangani pasar kota Madinah, dan lainlain. Al-Maududi juga menjelaskan bahwa "Tempat wanita adalah di rumah, tidak dibebaskan merka dari pekerjaan luar rumah kecuali agar merka selalu berada di rumah dengan tenang dan terhormat agar merka dapat melaksanakan kewajiban rumah tangga. Adapun kalau ada keperluannya untuk keluar, maka boleh saja merka keluar rumah dengan syarat memperhatikan segi kesucian diri dan memelihara kehormatannya". Pendapat Maududi ini jelas mengisyaratkan bahwa wanita boleh saja bekerja di luar rumah. Dalam hal ini Sayyid Qutb dalam tafsirnya Fi Dzilal al-Qur'an menyatakan bahwa ayat tersebut tidak berarti merka tidak boleh keluar rumah, tetapi hanya mengisyaratkan bahwa rumah tangga adalah tugas pokoknya, sedang selainnya adalah tempat di mana ia tidak menetap, dan bukan tugas

${ }^{32}$ S.M. Khamenei, Risalah Hak Asasi Wanita, "Studi Komparatif antara Pandangan Islam dan Deklarasi Universal HAM", diterjemahkan oleh Quito R. Motinggo, (Jakarta: Penerbit al-Huda, 2004), hal. 76-77. 
pokoknya. ${ }^{33}$ Dari berbagai pendapat yang sudah dikemukakan dapat dikatakan bahwa menurut hukum Islam perempuan memiliki hak untuk melakukan apapun asal tetap sesuai dengan ketentuan yang ada dalam al-Qur'an dan as-Sunnah.

e. Hak dan Kewajiban Belajar. Cukup banyak ayat al-Qur'an dan Hadits yang berbicara tentang kewajiban belajar, baik kewajiban tersebut ditujukan kepada lelaki maupun wanita. Para wanita pada zaman Nabi Muhammad saw sadar benar tentang kewajiban belajar itu, sehingga merka bermohon kepada Nabi Muhammad saw agar beliau bersedia menyisihkan waktu tertentu untuk membimbing merka menuntut ilmu. Al-Qur'an memberikan pujian keapa ulil $a l b a b$, yang berdzikir dan memikirkan tentang kejadian langit dan bumi. Dzikir dan pemikiran menyangkut hal tersebut mengantar manusia mengetahui rahasia-rahasia alam raya ini, dan hal tersebut tidak lain dari pengetahuan. Merka yang dinamai ulil albab tidak terbatas pada kaum lelaki saja, tetapi juga kaum perempuan. Hal ini sesuai dengan firman Allah surat Ali Imran ayat 195: "Maka Tuhan merka mengabulkan permohonan merka dengan berfirman: Sesungguhnya Aku tidak menyia-nyiakan amal-amal orang-orang yang beramal di antara kamu, baik lelaki maupun perempuan". Hal ini berarti bahwa perempuan bisa berpikir, belajar, kemudian mengamalkan pengetahuan yang merka miliki. Pengetahuan dalam hal ini tentunya tidak hanya pengetahuan yang ada kaitannya dengan hubungan manusia dengan Allah, tetapi juga pengetahuan alam raya ini, yang tentunya berkaitan dengan berbagai disiplin ilmu. Dengan demikian dari ayat di atas dapat dipahami bahwa perempuan bebas mempelajari apa yang dia minati sesuai dengan keinginan dan kecenderungan masing-masing. Cukup banyak wanita yang menonjol pengetahuannya dan menjadi rujukan sekian banyak tokoh lelaki. Sebagai contoh misalnya, isteri Nabi Muhammad saw, 'Aisyah r.a. adalah wanita yang pengetahuannya sangat mendalam dan dikenal sangat kritis, Asy-Syaikhah Syuhrah adalah salah seorang guru Imam Syafi'i, Rabi'ah al 'Adawiyah, dan lain-lain. ${ }^{34}$

f. Hak Perempuan di Bidang Politik. Hak-hak politik adalah hak-hak paling penting yang dinikmati oleh berbagai individu. Hak ini dapat membuat individu menjadi efektif dalam keuntungan politik, sosial dan ekonominya. Ia juga dapat menentukan peraturan pemerintah,

${ }^{33}$ M. Quraish Shihab, Op. Cit., hal. 7-11.

${ }^{34}$ Ibid., hal. 11-12. 
organisasi dan tata cara pelaksanaannya. Dengan demikian ia dapat mengambil bagian secara langsung dalam arus pelaksanaan hukum dan perundang-undangan. Dalam Islam, baik laki-laki maupun perempuan memiliki hak-hak utama politik yang meliputi antara lain hak memberikan suara, hak berserikat, berperang dan mempertahankan negara, dan hak untuk turut dalam diplomasi dan kesepakatan politik..$^{35}$ Ada beberapa ayat yang sering dipergunakan oleh beberapa ulama untuk dijadikan alasan melarang perempuan terlibat di bidang politik, antara lain surat an-Nisa' ayat 34, yang artinya: "lelaki adalah pemimpin bagi wanita...". Kemudian Hadits yang artinya: "Tidak akan berbahagia suatu kaum yang menyerahkan urusan merka kepada perempuan". Akan tetapi banyak mufassir kontemporer yang melihat bahwa ayat di atas tidak harus dipahami demikian, apalagi ayat tersebut berbicara dalam konteks rumah tangga. Adapun Hadits yang sudah disebutkan, dipahami sebagai kasus khusus, yang dibicarakan Nabi saw ketika beliau mendengar berita pengangkatan putri penguasa Persia sebagai pengganti ayahnya, yang mungkin anak perempuan tersebut tidak dipersiapkan pengetahuannya sebagaimana mestinya seorang pemimpin. Artinya jika perempuan itu mampu dan memenuhi syarat untuk menjadi penguasa, tentunya tidak ada masalah. Menurut Jamaluddin Muhammad Mahmud, tidak ada satupun ketentuan agama dalam Islam yang dapat dipahami bahwa wanita dilarang terlibat dalam bidang politik, atau ketentuan agama yang membatasi bahwa bidang politik tersebut hanya untuk kaum lelaki. Di sisi lain cukup banyak ayat dan Hadits yang dapat dijadikan dasar pemahaman untuk menetapkan hak-hak tersebut. Salah satu ayat yang sering kali dikemukakan oleh para pemikir Islam dalam kaitan dengan hak-hak politik perempuan adalah ayat 71 surat at-Taubah, yang artinya kurang lebih sebagai berikut: Dan orang-orang yang beriman, lelaki dan perempuan, sebagian merka adalah auliya' bagi sebagian yang lain. Merka menyuruh untuk mengerjakan yang ma'ruf, mencegah yang munkar, mendirikan shalat, menunaikan zakat, dan merka taat kepada Allah dan rasul-Nya. Merka itu akan diberi rahmat oleh Allah, sesungguhnya Allah Maha Perkasa lagi Maha Bijaksana“ (Q.s. at-Taubah: 71). Di samping itu al-Qur'an juga mengajak umat (lelaki dan perempuan) untuk bermusyawarah: "urusan merka (selalu) diputuskan dengan musyawarah" (Q.s. asy-Syura: 38). Ayat ini sering juga dijadikan dasar oleh banyak ulama untuk 
membuktikan adanya hak berpolitik bagi setiap lelaki dan perempuan. Dalam sejarah Islam cukup banyak wanita yang terlibat di bidang politik praktis, misalnya Ummu Hani', dibenarkan sikapnya oleh Nabi Muhammad saw, ketika memberi jaminan keamanan kepada sementara orang musyrik (jaminan keamanan merupakan salah satu aspek bidang politik). Bahkan 'Aisyah, isteri Nabi Muhammad sebagaimana sudah dikemukakan ia memimpin langsung peperangan melawan Ali bin Abi Thalib yang ketika itu menduduki jabatan kepala negara. Peperangan ini dikenal dengan "Perang Jamal (perang Unta)". Keterlibatan Aisyah r.a. bersama sekian banyak sahabat Nabi dan kepemimpinannya dalam peperangan itu menunjukkan bahwa beliau dan pengikutnya itu menganut pendapat yang menyatakan bahwa perempuan boleh terlibat dalam politik praktis. Dengan ilmu pengetahuan dan keterampilan yang dimiliki oleh setiap orang termasuk kaum perempuan, merka berhak untuk bekerja dan menduduki jabatanjabatan tertinggi. Dalam beberapa kitab Hukum Islam, seperti alMughni ditegaskan: "Setiap orang yang memiliki hak untuk melakukan sesuatu, maka sesuatu itu dapat diwakilkannya kepada orang lain, atau menerima perwakilan dari orang lain“. Atas dasar kaidah di atas, Jamaluddin Muhammad Mahmud berpendapat bahwa berdasarkan kitab Fikih, bukan hanya sekedar pertimbangan perkembangan masyarakat, kita dapat menyatakan bahwa perempuan dapat bertindak sebagai pembela dan penuntut dalam berbagai bidang". 36

Ketentuan-ketentuan hak-hak perempuan dalam ayat-ayat al-Qur'an dan Hadits itu kemudian dijadikan dasar negara-negara Islam yang tergabung dalam The Organization of The Islamic Conference (OIC/OKI) untuk merumuskan Pasal-pasal yang terdapat dalam Cairo Declaration. Dalam Cairo Declaration Pasal 1 disebutkan:

a. Semua manusia adalah satu keluarga, di mana setiap anggota keluarga bersatu dengan taat kepada Tuhan dan semuanya adalah keturunan Nabi Adam. Semua manusia sederajat dalam berhubungan sesamanya dalam melaksanakan kewajiban-kewajiban serta tanggungjawab yang mendasar tanpa ada diskriminasi dalam ras, warna kulit, bahasa, jenis kelamin, agama dan kepercayaan, aliran politik, status sosial, atau pertimbangan lainnya. Keyakinan yang

${ }^{36}$ Quraish Shihab, Op. Cit., hal. 13-16. 
benar menjamin derajatnya yang mengarah pada kemanusiannya yang sempurna.

b. Manusia adalah makhluk Tuhan dan sangat disayangi-Nya ialah yang sangat berguna bagi hamba-Nya yang lainnya dan tidak seorangpun dinilai lebih dari yang lainnya, kecuali berdasarkan ketakwaan dan amal baiknya.

Pasal tersebut sesuai dengan Pasal 2 Universal Declaration of Human Rights yang sudah disebutkan. Sedangkan mengenai persamaan antara lakilaki dengan perempuan dalam Cairo Declaration (CD) ditegaskan dalam Pasal 6:

a. Perempuan memiliki hak yang sama dengan laki-laki dalam mempertahankan derajat kemanusiannya dan memiliki hak-hak untuk menikmati hak persamaan tersebut di samping melaksanakan kewajiban-kewajibannya, memiliki hak sipil dan kebebasan yang berhubungan dengan keuangan dan hak untuk menjaga nama baik pribadi dan keturunannya.

b. Suami bertanggungjawab untuk memberikan nafkah dan kesejahteraan kepada keluarganya.

Dari Pasal $6(C D)$ dapat disimpulkan bahwa dalam $(C D)$ sebagaimana juga dalam al-Qur'an dan as-Sunnah perempuan sama derajatnya dan berhak menikmati hidup sesuai dengan tugas dan tanggungjawabnya. Di samping itu perempuan juga memiliki hak sipil sebagaimana laki-laki seperti menuntut ilmu, bekerja, dan lain sebagainya. Namun dalam hal berkeluarga dalam Pasal 6 huruf $\mathrm{b}$ disebutkan bahwa suamilah yang berkewajiban memberi nafkah, melindungi dan memberi kesejahteraan kepada keluarga.

Sebenarnya masih banyak hak-hak perempuan dalam berbagai bidang yang dapat dibahas, namun kajian hak perempuan ini dapat disimpulkan bahwa hak-hak perempuan sama dengan hak-hak laki-laki. Apabila ada perbedaan, itu hanyalah akibat fungsi dan tugas-tugas utama yang dibebankan Tuhan kepada masing-masing jenis kelamin. ${ }^{37}$

Yang pasti, dalam hukum Islam harus diterapkan keadilan baik bagi kaum laki-laki maupun kaum perempuan. Dalam hukum Islam, adil adalah titik tolak, proses dan tujuan. Keadilan tidak hanya diterapkan di bidang hukum tetapi juga di bidang-bidang lain termasuk bidang sosial, budaya, ekonomi, politik dan lain-lain.

${ }^{37}$ Ibid., hal. 13-16. 


\section{Penutup}

Islam sangat menghargai hak asasi manusia termasuk hak-hak perempuan. Fakta telah membuktikan bahwa risalah Islam sejak permulaannya di kota Suci Mekkah tidak membedakan hak-hak perempuan dan hak-hak laki-laki. Apabila ada perbedaan, itu hanyalah akibat fungsi dan tugas-tugas utama yang dibebankan Tuhan kepada masing-masing jenis kelamin. Setiap orang Islam harus memahami hukum Islam dengan baik dan dan benar, sehingga dia dapat menyadari hak dan kewajibannya sebagai hamba Allah, sebagai anggota masyarakat dan warga negara. Masalah HAM dan perempuan, hendaknya dipersepsi sebagai masalah yang dihadapi tidak hanya oleh kaum perempuan belaka, tetapi juga oleh semua lapisan masyarakat. Kesadaran mengenai hak-hak perempuan dalam Islam tidaklah dapat tercipta dengan sendirinya tetapi harus diusahakan melalui sosialisasi pemahaman yang benar kepada masyarakat khususnya umat Islam baik lakilaki maupun perempuan. Adapun pelaksanaannya sangat tergantung pada komitmen bersama antara pemerintah, masyarakat khususnya umat Islam, dan kaum perempuan itu sendiri. Wallahu a'lam. 


\section{Daftar Pustaka}

Ali, Mohammad Daud Ali. Pendidikan Agama Islam, Jakarta: PT. RajGrafindo Persada, 1998

, dan Habibah Daud. Lembaga-lembaga Islam di Indonesia, Jakarta: PT. RajaGrafindo Persada, 1995.

Al-Faruqi, L. "Islamic Traditions and Feminist Movement: Confrontation or cooperation", The Islamic Quarterly, Vol. XXVII, No. 3, 1983: 136.

Jawad, Haifaa A. Otentisitas Hak-hak Perempuan, Perspektif Islam Atas Kesetaraan Jender, diterjemahkan oleh Anni Hidayatun Noor, Sulhani Hermawan dan H. Badrian, Yogyakarta: Fajar Pustaka Baru, 2002.

Gauhar, Altaf. Tantangan Islam, diterjemahkan oleh Anas Mahyuddin, Bandung: Pustaka, 1982.

Al-Hamid, Muhammad. Islam Rahmat bagi Wanita, diterjemahkan oleh Kathur Suhardi, Surabaya: Risalah Gusti, 1992.

Hasanah, Uswatun dan Mutiara Hikmah. Hak-hak Perempuan, Depok: Sentra HAM FHUI-BAKESBANG DKI Jakarta, 2003.

Hussain, Syekh Syaukat. Hak Asasi Manusia dalam Islam, diterjemahkan oleh Abdul Rochim, Jakarta: Gema Insani Press, 1996.

International Labour Organization, Apa Itu Gender?, Jakarta: ILO, 1997

Neufeld, Victoria (ed.). Webster's New World Dictionary, New York: Webster's New World Clevenland, 1984.

Khamenei, SM. Risalah Hak Asasi Wanita, Studi Komparatif antara Pandangan Islam dan Deklarasi Universal HAM, diterjemahkan oleh Quito R. Motinggo, Jakarta: Penerbit al-Huda, 2004

Natsir, Lies M. Marcoes dan Hendrik. Wanita Islam Indonesia dalam Kajian Tekstual dan Kontektual Jakarta: INIS, 1993.

Saefuddin, Ahmad M. Ekonomi dan Masyarakat dalam Perspektif Islam, Jakarta: Rajawali, 1987.

Shihab, M. Quraish. Perempuan, Cetakan ke V, Tangerang: Lentera Hati, 2009.

Subono, Nur Iman (ed.). Negara dan Kekerasan Terhadap Perempuan, Jakarta: Yayasan Jurnal Perempuan, 2000. 
Thalib, Sajuti. Hukum Kewarisan Islam di Indonesia, Jakarta: Sinar Grafika, 1995.

Umar, Nasaruddin. Argumen Kesetaraan Jender Perspektif al-Qur'an, Jakarta: Paramadina, 2001.

Yierney, Helen (ed.). "Women's Study Encyclopedia", Vol. I, New York: Green Wood Press.

\section{Instrumen HAM Internasional}

Universal Declaration of Human Right, 1948.

Vienna Declaration, 1986.

Convention On The Elimination Of All Forms Of Discrimination Against Women (CEDAW), 1979.

Declaration On The Elimination Of Violence Against Women, 1994.

Cairo Declaration, 1990. 